\title{
Construction of Practical Training Model of Bidding Ability under the Background of New Subject
}

\author{
Liu Jing'ai and Zhang Li
}

\begin{abstract}
The new subject is Educational Training Plan for Excellent Engineers (Edition 2.0). It emphasizes the integration of multi-disciplines and multi-subject participation, which is of great significance to promote higher education to cultivate talents for social needs. Bidding is the core course of engineering management specialty. In view of the current situation that the bidding practice is broken up, this paper intends to integrate the relevant course training links and construct seven training modules. Through the perfect evaluation system, the bidding teaching and training system adapted to the requirements of the new subject will be formed.
\end{abstract}

Index Terms-Bidding core competence, emerging engineering education, practice module.

\section{INTRODUCTION}

The Education and Training Plan for Excellent Engineer version 2.0 [1] of The Emerging Engineering Education Construction Project [2] is a way for higher education to thoroughly study and implement President Xi Jinping's socialism with Chinese characteristics in the new era, and also one of a series of measures to improve quality, promote fairness, create new talents and promote the construction of practical training mechanism [3]. The plan reflects the characteristics of the times, with new and rich connotations, emphasizes the blending of many subjects, attaches importance to the participation of multiple subjects, and covers a wide range of aspects. It cultivates a lot of talents with practical ability, which can meet the challenge of the new economy, serve the national strategy and meet the needs of the industry [4]. As a student majoring in engineering management, bidding is one of the most important courses [5] but the comprehensive practice of bidding involves many courses, such as Engineering Valuation and Measurement, Engineering Bidding and Contract Management, Construction Technology, Construction Organization Design and Engineering Project Management, etc. In the past each course is followed by one course design and practical training. According to the requirements of the construction of Emerging Engineering Education, our work can cross and merge many subjects, establish modules and form practical training systems, so as to achieve theoretical knowledge integration and help students enter into roles and be competent workers as soon as possible after graduation. Colleges try to accomplish the goal of turning out the application-oriented, technology-oriented and

Manuscript received May 14, 2019; revised June 23, 2019.

The authors are with Shandong Agriculture and Engineering University, Shandong, China (e-mail: 13605315003@163.com,441428594@qq.com). inter-disciplinary talents. This requires engineers and technicians to have both relevant theoretical knowledge and practical operational skills in bidding. Therefore, in the process of training, students must have a solid theoretical knowledge base, practical professional technology, good professional accomplishment, strong learning ability, clear expression ability and pioneering innovation ability. They are required to meet the needs of the market and become senior technical and applied expertise to engage in bidding and contract management in the field of engineering construction.

\section{ANALysis ON THE PRESENT Situation AND PROBLEMS OF ENGINEERING BIDDING TEACHING PRACTICE TRAINING}

We take the practice training of engineering management bidding teaching in our college as an example, combined with the investigation and research of other four applied architecture colleges and universities in Shandong province. The main problems are scattered curriculum practice, lacking of systematicness and unity and difficulty in achieving systematic training of theoretical knowledge in the core competence of bidding, which can be seen from the following aspects:

\section{A. Teaching Practice and Training are Scattered and not Systematic}

The teaching practice of core competence in engineering inviting bids and submitting bids is a systematic work. However, at present, the engineering management major in our college adopts the mode of scattered practice according to the curriculum, and the practice arranges the project and content only according to the needs of the course itself. Lack of system and unity prevents students from forming a complete concept of engineering construction. For example, when the course of Construction Organization Design is finished, the teaching practical training project will arrange a network plan of the project, and after the course Construction Technology and Management is the construction scheme of the simulated project. At the same time, some practical contents will overlap in different courses, for example, the engineering quantity list from Engineering Metrology Rules will repeatedly appear in the preparation of bidding documents list. Some results of practice cannot be fully utilized, and some experimental classes are difficult to organize because of lack of data.

\section{B. Practical Teaching Resources Are not Perfect and Updating Is not Timely}

As a result of the changes in the economic and social situation, the level of science and technology and the national macro policy, the social demand for construction engineering 
management talents change, which requires the constant updating of the practical teaching in this major. In addition, at present, the form of practical teaching of architectural engineering management major is relatively simple, and the practice teaching is mainly based on teaching experiment, which has great limitations on the cultivation of students' comprehensive ability and practical operation ability. For example, in terms of project cost, the state and the provinces and cities issue and adjust the engineering pricing and measurement rules at regular intervals. Without timely updating, the significance of exercise cannot be achieved. The original engineering construction technology was old, such as the clay brick and concrete structure. In 2018, our comprehensive training building of the teaching experiment finished its design and began its construction. All engineering materials and processes are reactive low-carbon environmental friendly materials and new processes.

\section{The Practice Content of Relevant Specialized Courses} Is Insufficient and the Order of Opening is Unreasonable

The practice content of related courses is not enough and the rate of opening is not high, which is basically taught in class. Even for those opened practice, because the number of people in the same time is too large while the guidance teachers are less, the operating time and the guided time of each student are too short to achieve the ideal effect. And the order of the related courses before and after opening is unreasonable. As a result, the project-oriented core competence of bidding cannot be realized. For example, Reinforced Concrete and Construction Technology should be opened in front of Engineering Pricing and Measurement Rules, since without a clear understanding of the basic technical parameters, it is impossible to set up the pricing quota support. Therefore, combing the construction of practical training ability with engineering bidding as the core is conducive to arranging the course sequence of specialty, recombining and establishing curriculum system, and improving the teaching ability and level of engineering management specialty [6].

\section{Construction OF Teaching AND TRAining Model FOR BIDDING}

\section{A. Division of Bidding Stages and Capacity Requirements}

Project tendering and bidding is the agreement that the tenderer chooses the object and object of contract transaction through the normative procedure of fair competition and fair evaluation, and finally forms the rights, obligations and responsibilities of the contract. The process includes bidding, bidding, opening, evaluating, calibrating and signing contracts. According to the different abilities of different positions at different stages, the corresponding professional basic courses and professional courses are different, as detailed in Table I.

\begin{tabular}{|l|l|l|l|}
\multicolumn{4}{c|}{ TABLE I: JOB COMPETENCY ANALYSIS } \\
\begin{tabular}{|l|l|l|l|}
\hline $\begin{array}{l}\text { Occupation } \\
\text { post }\end{array}$ & $\begin{array}{l}\text { Task } \\
\text { phase }\end{array}$ & $\begin{array}{l}\text { capacity } \\
\text { requirements }\end{array}$ & $\begin{array}{l}\text { correlated } \\
\text { curriculum }\end{array}$ \\
\hline
\end{tabular}
\end{tabular}

\begin{tabular}{|c|c|c|c|}
\hline $\begin{array}{l}\text { 1.Tenderee } \\
\text { (bidding } \\
\text { agency) } \\
\text { 2.Bidding } \\
\text { management } \\
\text { post }\end{array}$ & $\begin{array}{l}\text { 1.Drawing up } \\
\text { the bidding } \\
\text { scheme } \\
\text { 2.Inviting bid, } \\
\text { submitting bid, } \\
\text { bid opening, } \\
\text { bid deciding } \\
\text { 3.Preparation of } \\
\text { prequalification } \\
\text { documents } \\
\text { 4.Prepare } \\
\text { tender } \\
\text { documents } \\
\text { 5. Sign a } \\
\text { contract }\end{array}$ & $\begin{array}{l}\text { 1. Master the } \\
\text { basic theory } \\
\text { and knowledge } \\
\text { of engineering } \\
\text { bidding; } \\
\text { 2.Master } \\
\text { engineering } \\
\text { technical } \\
\text { standards and } \\
\text { requirements; } \\
\text { 3. Master the } \\
\text { calculation } \\
\text { rules and } \\
\text { compilation of } \\
\text { bill } \\
\text { quantities; of } \\
\text { 4.Master the } \\
\text { principle of } \\
\text { group price and } \\
\text { compilation } \\
\text { method; } \\
\text { 5.Master } \\
\text { negotiation } \\
\text { skills } \\
\text { contract in } \\
\text { negotiation. }\end{array}$ & $\begin{array}{l}\text { Project Bidding } \\
\text { and Contract } \\
\text { Management, } \\
\text { Construction } \\
\text { Technology, } \\
\text { Engineering } \\
\text { Measurement } \\
\text { and } \\
\text { Evaluation. }\end{array}$ \\
\hline $\begin{array}{l}\text { 1.Tenderer } \\
\text { 2.Bidding } \\
\text { management } \\
\text { post }\end{array}$ & $\begin{array}{l}\text { 1. Organize bid } \\
\text { 1.1.prepare } \\
\text { prequalification } \\
\text { application } \\
\text { documents } \\
\text { 2.Preparation of } \\
\text { tender } \\
\text { documents } \\
\text { 2.1.preparation } \\
\text { of technical } \\
\text { tender } \\
\text { 2.2.preparation } \\
\text { of commercial } \\
\text { bid } \\
\text { 3. Sign a } \\
\text { contract }\end{array}$ & $\begin{array}{l}\text { 1. Master the } \\
\text { basic theory of } \\
\text { bidding } \\
\text { knowledge } \\
\text { 2.Master } \\
\text { construction } \\
\text { organization } \\
\text { and technology } \\
\text { 3.Master the } \\
\text { method of } \\
\text { project } \\
\text { management } \\
\text { 4.Master } \\
\text { bidding } \\
\text { quotation } \\
\text { principle and } \\
\text { preparation } \\
\text { method } \\
\text { 5.Mastering the } \\
\text { negotiation } \\
\text { skills } \\
\text { contract of } \\
\text { negotiation }\end{array}$ & $\begin{array}{l}\text { Engineering } \\
\text { Bidding and } \\
\text { Contract } \\
\text { Management, } \\
\text { Construction } \\
\text { Technology, } \\
\text { Construction } \\
\text { Organization, } \\
\text { Engineering } \\
\text { Project } \\
\text { Management, } \\
\text { Engineering } \\
\text { Measurement } \\
\text { and } \\
\text { Evaluation. }\end{array}$ \\
\hline
\end{tabular}

\section{B. Core Competency Module for Bidding in Engineering Management}

TABLE II: COMPARISON BETWEen MOdULE CONSTRUCTION AND RELATED PROFESSIONAL PRACTICE

\begin{tabular}{|c|c|c|}
\hline Core ability & Ability decomposition & $\begin{array}{l}\text { Practice } \\
\text { module }\end{array}$ \\
\hline \multirow{3}{*}{ Bidding } & \multirow{3}{*}{$\begin{array}{l}\text { Preparation of } \\
\text { tender documents }\end{array}$} & $\begin{array}{l}\text { Module 1: } \\
\text { drawing and } \\
\text { reading of } \\
\text { construction } \\
\text { drawings }\end{array}$ \\
\hline & & $\begin{array}{c}\text { Module 2: } \\
\text { preparation of } \\
\text { engineering } \\
\text { tender } \\
\text { documents }\end{array}$ \\
\hline & & $\begin{array}{c}\text { Module 3: } \\
\text { preparation of } \\
\text { bill of } \\
\text { quantities and } \\
\text { bid control }\end{array}$ \\
\hline
\end{tabular}




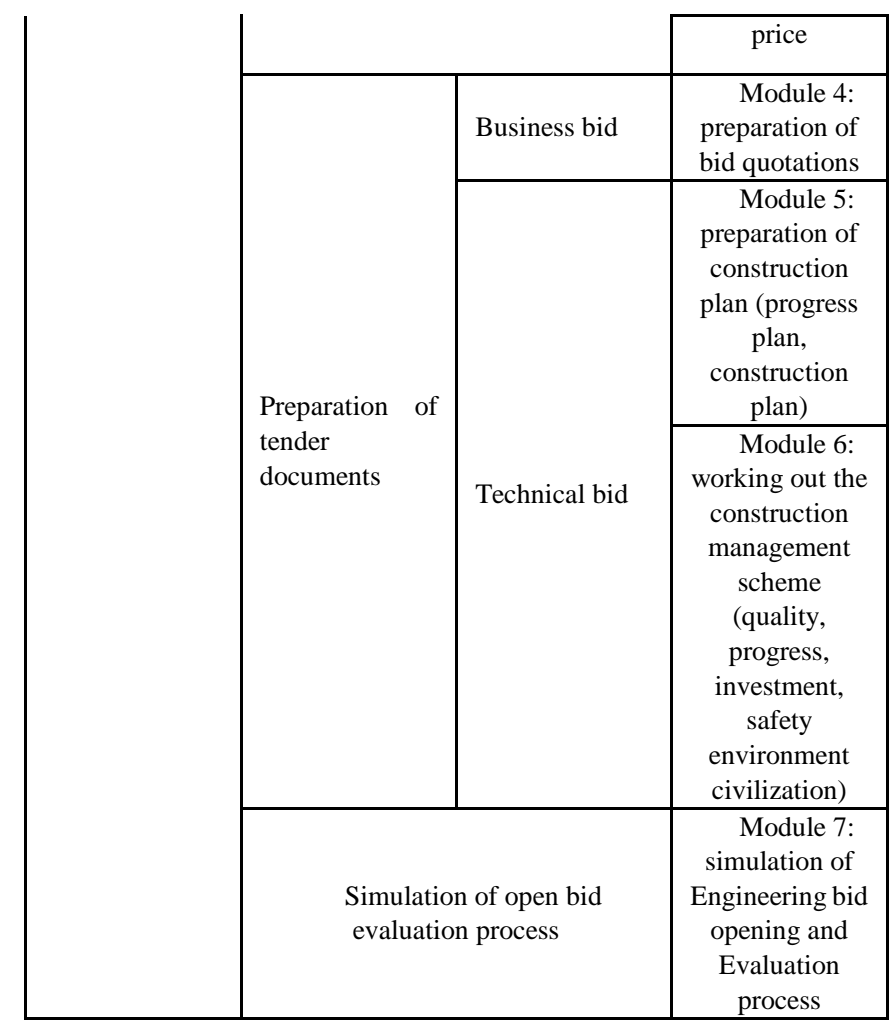

Taking engineering management specialty as an example, according to different stages and different job capacity requirements, combined with the construction of teaching system, optimize the assessment system, and build seven modules (see Table II \& III). According to the seven modules, different practice contents are offered, which are applied in engineering management courses, practical teaching links and graduation design to improve the core competence of bidding. as shown in Fig 1.

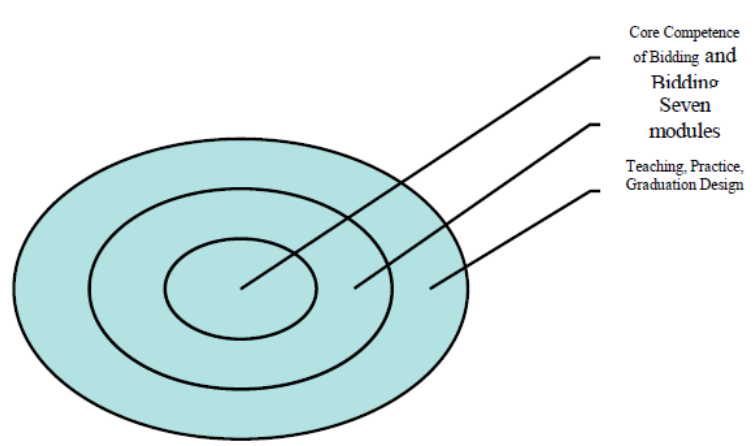

Fig. 1. The schematic diagram of core competencies and practice modules for bidding.

\section{Application of Teaching and Training Module in Engineering Bidding}

The training objectives of engineering management professionals are: to develop morally, intellectually, physically and aesthetically in an all-round way, to meet the needs of modern construction, to take engineering project management as the main line, to master the basic professional knowledge of "Construction Technology", "Construction Engineering Economy", "Reinforced Concrete", "Engineering Valuation Measurement Rules" and so on, to have certain bidding ability, and to engage in construction project management. Senior applied talents in the work. According to the goal of personnel training, the characteristics of Application-oriented Colleges and Universities under the background of new engineering [7], combined with practice module in professional courses and professional practice teaching, according to the application of different courses and periods, are as follows [8]. Which is detailed in Table III.

In Table III, the practice module in professional courses and professional practice teaching can be divided seven parts. such as: Module 1(M1): construction drawings read; Module 2(M2): preparation of tender documents; Module3(M3): preparation of bill of quantities and bid control price; Module 4(M4): compiling bid quotations; Module5(M5): design construction plan; Module6(M6): desi Construction Management; Module7(M7): simulating the open bid evaluation process.

Some proper nouns are going to be replaced by some acronyms, such as: Practice (P), Term (T), Name (N).

\section{Application and Evaluation of Teaching and Training Module in Bidding}

In view of the design of the practice module, we can explore a variety of flexible teaching methods, adapt to the practice module teaching, and achieve the goal of improving the overall quality of students. In the role simulation teaching method, the students take the group as the unit, simulate the enterprise entity to compile the bidding documents, in the bidding, evaluation and calibration links, the students simulate the role and complete the bidding work [9]. In the teaching of bidding and contract management, we should carry out case teaching method, make full use of the cases that teachers have participated in the project bidding and tendering, and process the typical projects, project demonstration, pre-qualification, tendering, tender opening, tender evaluation, final tender, psychological feelings of both parties in the field bidding and tendering into lively and attractive teaching cases, so as to enable students to collect cases in advance. Preparing to report PPT, each group selected a representative to explain, the students asked questions on the spot, and then the teacher summarized the experience and lessons in the case. The method of teaching and learning exchange can arouse students' enthusiasm for learning, enthusiasm of thinking and consciousness of acquiring knowledge. There are some simple and understandable chapters in the classroom. Let the students teach on their own. Open teaching method, teachers can make full use of social resources to deepen students' understanding and mastery of the curriculum, organize students to visit the construction project trading center, and observe the actual bidding conference.

The assessment of practice module in the course can be combined with the requirements of the syllabus. The assessment in peacetime accounts for $30 \%$ of the total score, and the final assessment accounts for $70 \%$ of the total score. The assessment in peacetime can be changed to the assessment in practice. Practice assessment results course is mainly evaluated from three aspects: attendance, classroom performance and practice results. The assessment results of the practice module set up in the professional practice teaching link are mainly evaluated from four aspects: attendance, practice performance, practice results and practice defense. 
TABLE III: APPLICATION OF PRACTICE MODULE IN ENGINEERING MANAGEMENT SPECIALTY

\begin{tabular}{|c|c|c|c|c|c|c|}
\hline \multirow{2}{*}{$\mathrm{N}$} & \multirow{2}{*}{ Content } & \multicolumn{2}{|c|}{ Offering courses } & \multicolumn{2}{|c|}{ Professional practice teaching } & \multirow{2}{*}{ Practice goals } \\
\hline & & $\mathrm{N}$ & $\mathrm{T}$ & $\mathrm{N}$ & $\mathrm{T}$ & \\
\hline \multirow{5}{*}{ M 1} & $\begin{array}{l}\mathrm{P} 1 \text { : } \\
\text { Basic practice of map } \\
\text { recognition }\end{array}$ & $\begin{array}{l}\text { Architectural map } \\
\text { recognition and CAD }\end{array}$ & 1 & & & $\begin{array}{l}\text { Develop the ability to read engineering } \\
\text { drawings and solve practical roblems; } \\
\text { Master the basic rules of drawing; Master } \\
\text { the ommon expressions and graphic } \\
\text { features of architectural construction } \\
\text { drawings; Cultivate a rigorous and } \\
\text { meticulous working style; }\end{array}$ \\
\hline & $\begin{array}{l}\text { P 2: } \\
\text { Auto CAD software } \\
\text { learning }\end{array}$ & $\begin{array}{l}\text { Architectural map } \\
\text { recognition and CAD }\end{array}$ & 1 & & & $\begin{array}{l}\text { Familiar with AutoCAD interface and } \\
\text { drawing environment; Master basic } \\
\text { drawing commands; Master layers, object } \\
\text { characteristics and dimensioning } \\
\text { methods; }\end{array}$ \\
\hline & $\begin{array}{l}\text { P3: } \\
\text { Construction Reading }\end{array}$ & & & $\begin{array}{l}\text { Construction } \\
\text { Drawing Practice }\end{array}$ & 2 & $\begin{array}{l}\text { Read the construction drawings and } \\
\text { prepare for the correct drawing }\end{array}$ \\
\hline & $\begin{array}{l}\text { P 4: } \\
\text { Hand-drawn } \\
\text { construction drawings }\end{array}$ & & & $\begin{array}{l}\text { Practical training } \\
\text { on Reading and } \\
\text { drawing } \\
\text { Architectural } \\
\text { Construction } \\
\text { drawings }\end{array}$ & 2 & $\begin{array}{l}\text { Grasp the engineering drawing standards } \\
\text { and mark them in common use; Grasp the } \\
\text { reading methods and steps; Hand-drawn } \\
\text { drawing methods and steps. }\end{array}$ \\
\hline & $\begin{array}{l}\text { P 5: } \\
\text { Mechanical } \\
\text { construction drawing }\end{array}$ & & & $\begin{array}{l}\text { Practical training } \\
\text { on Reading and } \\
\text { drawing } \\
\text { Architectural } \\
\text { Construction } \\
\text { drawings }\end{array}$ & 2 & $\begin{array}{l}\text { mastering basic drawing commands, } \\
\text { editing commands and modifying } \\
\text { commands ; mastering the simple steps } \\
\text { and methods of drawing construction } \\
\text { drawings on facades and facades; }\end{array}$ \\
\hline \multirow[t]{2}{*}{ M2 } & $\begin{array}{l}\text { P 1: } \\
\text { Pre-qualification of } \\
\text { tender announcement }\end{array}$ & $\begin{array}{c}\text { Bidding and contract } \\
\text { Management }\end{array}$ & $\begin{array}{c}\text { Term } \\
2\end{array}$ & & & $\begin{array}{l}\text { mastering the contents of the tender } \\
\text { announcement and the prequalification } \\
\text { documents; mastering the prequalification } \\
\text { procedure; mastering the manner in which } \\
\text { the tender announcement is issued }\end{array}$ \\
\hline & $\begin{array}{l}\text { P 2: } \\
\text { Tender documents }\end{array}$ & & & & & $\begin{array}{c}\text { master the preparation steps of bidding } \\
\text { documents; master the contents of tender } \\
\text { documents. }\end{array}$ \\
\hline \multirow{4}{*}{ M3 } & $\begin{array}{l}\text { P1: } \\
\text { Quotation Cost } \\
\text { Document }\end{array}$ & $\begin{array}{l}\text { Construction } \\
\text { engineering } \\
\text { valuation }\end{array}$ & 3 & & & $\begin{array}{l}\text { Grasp the basic principle of valuation with } \\
\text { bill of quantities; Grasp the cost } \\
\text { composition of bill of quantities; Grasp } \\
\text { the format and content of bidding } \\
\text { documents. }\end{array}$ \\
\hline & $\begin{array}{l}\text { P 2: } \\
\text { Bill of Quantities }\end{array}$ & & & $\begin{array}{l}\text { Decoration } \\
\text { Measurement and } \\
\text { Valuation }\end{array}$ & 4 & $\begin{array}{c}\text { Master the calculation method of } \\
\text { decoration engineering quantity; Master } \\
\text { the content and format of decoration } \\
\text { engineering quantity list. }\end{array}$ \\
\hline & $\begin{array}{l}\text { P 3: } \\
\text { Bidding Control Price } \\
\text { (Manual) }\end{array}$ & & & $\begin{array}{l}\text { Decoration } \\
\text { Measurement and } \\
\text { Valuation }\end{array}$ & 4 & $\begin{array}{l}\text { Master the principle of price control in } \\
\text { decoration project bidding; Master the } \\
\text { content and requirements of price control } \\
\text { in decoration project bidding. }\end{array}$ \\
\hline & $\begin{array}{l}\text { P 4: } \\
\text { Pr Compiling Bill of } \\
\text { Quantities } \\
\text { (Computerized) }\end{array}$ & $\begin{array}{l}\text { Application of } \\
\text { engineering cost } \\
\text { software }\end{array}$ & 5 & & & $\begin{array}{l}\text { Master the method of building cost } \\
\text { software civil engineering and reinforcing } \\
\text { bar model; Master the way of project } \\
\text { setting; Master the calculation of civil } \\
\text { engineering and reinforcing bar quantity } \\
\text { and output of results. }\end{array}$ \\
\hline M4 & $\begin{array}{l}\text { P } 1 \\
\text { Bidding quotation } \\
\text { (manual calculation) }\end{array}$ & & & $\begin{array}{l}\text { Decoration } \\
\text { Measurement and } \\
\text { Valuation }\end{array}$ & 4 & $\begin{array}{l}\text { Master the principle and method of } \\
\text { bidding quotation compilation for } \\
\text { decoration projects; Master the content } \\
\text { and format requirements. }\end{array}$ \\
\hline M 5 & $\begin{array}{l}\text { P 1: } \\
\text { Draw up the } \\
\text { construction plan }\end{array}$ & $\begin{array}{l}\text { Construction } \\
\text { technology }\end{array}$ & 3 & $\begin{array}{l}\text { Practical training of } \\
\text { Construction } \\
\text { Technology and } \\
\text { Construction } \\
\text { Scheme } \\
\end{array}$ & 3 & $\begin{array}{l}\text { Master the main contents of the } \\
\text { construction plan. Master the construction } \\
\text { process and construction technology of } \\
\text { sub-projects. }\end{array}$ \\
\hline M 6 & no & & & & & \\
\hline M7 & $\begin{array}{l}\text { P 1: } \\
\text { Simulat Bid Opening } \\
\text { and Evaluation }\end{array}$ & $\begin{array}{c}\text { Bidding and contract } \\
\text { Management }\end{array}$ & 2 & & & $\begin{array}{l}\text { Master the bidding procedure, Master the } \\
\text { composition, procedure and content of the } \\
\text { tender evaluation committee. }\end{array}$ \\
\hline
\end{tabular}

\section{CONCLUSION}

According to relevant requirements, the ten basic abilities required for the engineering management profession include: the ability to work out project proposals and research reports, the ability to work out project planning reports, the ability to organize, design and manage the planning and preparation of 
planning, the ability to prepare bidding documents, the ability to prepare the project contract documentation, the ability to design construction organization, arrange the process and resources, the ability to make engineering pre-settlement documentation capacity, the ability to plan investment cost , the ability to manage software application and the ability to manage document writing. The practice module of the core competence of bidding based on the actual engineering involves five of the ten abilities, and these five abilities are the important abilities that should be cultivated in such applied colleges and universities as our college. When the main courses of engineering management specialty are connected by the line of engineering bidding process and ability requirement, the course system oriented to engineering is reconstructed, and the training standards and various requirements are put into practice. We pay attention to the practicality of curriculum by integrating knowledge imparting and ability cultivation to practical courses, so as to promote the transformation of engineering management specialty teaching from scientific paradigm to engineering paradigm.

This subject preliminarily studies the construction of the practice module system of the core competence of bidding based on the actual engineering. There are still many deficiencies in the project, and then there are still many parts for further study, such as improving the implementation details of the practice module, working out the practice outline and practice instruction, and establishing a case base that conforms to the requirements of the engineering paradigm for the engineering management specialty. On this basis, the application of engineering paradigm in engineering management specialty teaching is systematically studied.

\section{CONFLICT OF INTEREST}

The authors declare no conflict of interest.

\section{AUTHOR CONTRIBUTIONS}

Liu Jingai conducted the research; Liu Weiqing collected the data; all authors had approved the final version.

\section{REFERENCES}

[1] Ministry of Education, Outline of the National Medium-Term and Long-Term Education Reform and Development Plan (2010-2020), and Outline of the National Medium-term and Long-Term Talents Development Plan (2010-2020).

[2] Ministry of Finance, Ministry of Finance of the National Development and Reform Commission of the Ministry of Education, On Guiding the Transformation of Some Local Colleges and Universities into Application (2015, Number 7)
[3] X. M. Fang, "Exploration of the motive mechanism of school-enterprise cooperation in the training of outstanding Engineers," Education Review, pp. 27-29, 2013.

[4] J. Hong and X. Shu, "Study on the self-running ability of China Trade Association," Journal of Beijing Institute of Technology (Social Sciences Edition), pp. 50-54, 2012.

[5] H.-B. Kong and Y.-Q. Qiu, "Exploration of qualification framework and competency standards for engineers," Research on Higher Engineering Education, pp. 9-19, 2010.

[6] H. M. Li et al., "The reform of university curriculum system for strengthening the cultivation of engineering ability," Research on higher Engineering Education, pp. 140-144, 2013.

[7] F. Wang, "The employment ability training model of applied undergraduate college students based on career path," Jiangsu Higher Education, pp. 91-92, 2013.

[8] D.-Y. Yang, "The three dimensional connotation of students' practical ability," Modern University Education, pp. 6-11, 2012.

[9] Y. D. Zhu and Y. J. Ye, "Research on professional certification standards of engineering education in the United States," Modern University Education, pp. 46-50 2009.

Copyright (C) 2019 by the authors. This is an open access article distributed under the Creative Commons Attribution License which permits unrestricted use, distribution, and reproduction in any medium, provided the original work is properly cited (CC BY 4.0).

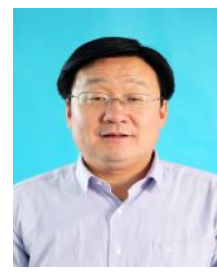

Liu Jingai was born in March 1979 in Jining, Shandong province. $\mathrm{He}$ is an associate professor. $\mathrm{He}$ received a bachelor's degree from Shandong University of Architecture and Engineering in July 2001. He received a master's degree in engineering project management, a master's degree in engineering project management, a national registered cost engineer, a supervisor and a consulting engineer (investment) from the School of Management, Shandong University in December 2010.

Mainly engaged in construction project management, engineering bidding and engineering quality control and other aspects of teaching, the main course is "Project Management", "Bidding and Contract Management", "Management" and "Construction Project Quality Control". In the field of engineering quality control and management, green building and green construction technology has been studied; in recent years, in the field of engineering project management and teaching. In terms of scientific research, 2 papers from SCI, 3 papers from EI and 5 papers on Chinese core teaching and research were published; 4 textbooks such as Construction Engineering Economy and Enterprise Management were compiled; 10 national and provincial topics were presided over or participated in.

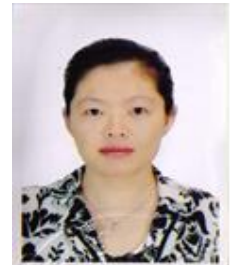

Zhang Li was born in July 1970. She is associate professor, director of Teaching and Research Department of Construction Engineering Management, Leader of Construction Engineering Management, Registered Cost Engineer. She got the master of architecture and civil engineering, Tongji University. Mainly engaged in the teaching and scientific research work of engineering cost and engineering management, undertook the teaching tasks of "Housing Structure", "Engineering Cost Valuation and Control", "Engineering Cost Measurement" and "Engineering Cost Software Application". He has participated in 2 provincial projects, 5 college-level projects, published 8 papers and compiled 2 textbooks. 